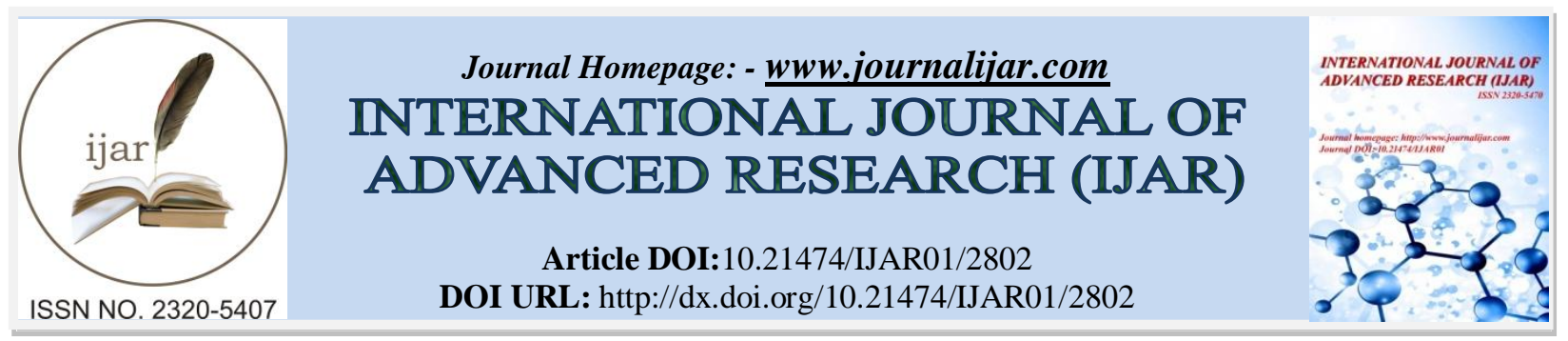

RESEARCH ARTICLE

\title{
PRETERM LABOUR: A STUDY OF ETIOLOGICAL RISKFACTORS AND PERINATAL OUTCOME.
}

\author{
Shilpa Dhingra ${ }^{1}$, Bhumika Shukla ${ }^{2}$ and Sudha Salhan ${ }^{3}$. \\ 1. Associate Professor, NDMC Medical College and Hindu Rao Hospital, Delhi. \\ 2. Senior Resident, NDMC Medical College and Hindu Rao Hospital, Delhi. \\ 3. Professor, NDMC Medical College and Hindu Rao Hospital, Delhi.
}

\section{Manuscript Info}

(.........................

\section{Manuscript History}

Received: 15 November 2016

Final Accepted: 17 December 2016

Published: January 2017

\section{Key words:-}

preterm labour, perinatal outcome, preterm premature rupture of membranes,

\section{Abstract}

Objective: To study the causes associated with preterm labour and the perinatal outcome in preterm labour.

Methods: This prospective observational study was conducted in the department of obstetrics and gynaecology NDMC Medical College and Hindu Rao Hospital over a period of 6 months (Jan to June 2016). All patients presented with preterm labour, preterm premature rupture of membrane and with conditions where labour was iatrogenicallyinduced prematurely were included in the study. All the patients were divided into four groups depending upon the gestational age - less than 28 weeks, 28 to 31 weeks, 32 to 34 weeks and more than 34 weeks. Risk factors and the perinatal outcome were analyzed.

Results: Out of 4382 patients delivered 946 were preterm delivery (21.5\%).54 out of 946 preterm deliveries had come with intrauterine death. The commonest risk factor of preterm delivery was preterm premature rupture of membrane followed by infection, anemia, preeclampsia and abruption. $73.2 \%$ of patients went into spontaneous preterm labour and $26.8 \%$ had caesarean section. Maximum perinatal complications and death were seen in group with gestational age less than 28 weeks.

Conclusions: The most common associated cause for preterm birth was preterm premature rupture of membrane. Perinatal outcome improves with gestational age. All preterm deliveries should be conducted in tertiarycare hospital where better neonatal care is available.

Copy Right, IJAR, 2016,. All rights reserved.

\section{Introduction:-}

WHO defines preterm birth as the delivery of an infant between 20 and less than 37 weeks of gestation. Preterm delivery is responsible for $70 \%$ of mortality and $75 \%$ of morbidity in the neonatal period [1]. Approximately 12.9 million babies worldwide are born too early every year, representing an incidence of preterm birth of $9.6 \%$ [2]. About $85 \%$ of all preterm births occur in Africa and Asia [3]. Preterm birth can be due to spontaneous preterm labour with intact membrane, preterm premature rupture of membranes and delivery for maternal and fetal indications. Spontaneous preterm labour and PPROM contributes to $70 \%$ of cases [4]. About $70 \%$ of cases are seen at late oestational aoe (24-36 weeks) I51 The nrerice etinloov is ctill unknowan Manv factore like nrior preterm

Corresponding Author:-ShilpaDhingra.

Address:-Associate Professor, NDMC Medical College and Hindu Rao Hospital, Delhi. 
deliveries, low social-economic status, extremes of maternal age, $(<17,>35$ years of age) and present obstetric complications like over distension of uterus, pre-eclampsia and antepartum haemorrhage are thought to be mainly responsible for onset of preterm labour [6].

Aims and objective:-

1. To find out the incidence, etiological risk factors responsible for pretermlabour.

2. To evaluate the perinatal outcome in preterm births.

\section{Material and Methods:-}

This prospective observational clinical study was carried out in 946 cases, between 20 weeks to less than 37 weeks of gestation, who presented with preterm labour, preterm premature rupture of membrane and with conditions where labour was iatrogenically induced prematurely were included in the study. The patients who presented with following signs and symptoms were included in the study:-

1. Painful uterine contractions four in $20 \mathrm{~min}$ with progressive cervical changes.

2. Cervical effacement of more than $80 \%$ and dilatation more than $1 \mathrm{~cm}$.

The duration of study was 6 months. All the cases were admitted in the labour room and the progress of labour was monitored. Obstetric management was done as per the findings in the individual case. Paediatricians were available at the time of delivery. All subjects and their babies were followed throughout their hospital stay. Associated maternal risk factors and perinatal outcomes were analyzed. Babies were transferred to premature baby care unit for neonatal care and neonatal outcome was analyzed.

\section{Results:-}

Total number of delivery in 6 months study period were 4382 . Out of 4382 deliveries, 946 were preterm birth $(21.5 \%)$. It was observed that $40 \%$ women were from poor social-economic status. $44.5 \%$ of cases had pregnancy duration of 34 to 37 weeks. $70 \%$ cases had some associated risk factor responsible for preterm labour. PPROM, hypertension and anemia were the common risk factors associated with preterm labour (Table 1). 73.2\% delivered vaginally and $26.8 \%$ cases were delivered by caesarean section. Perinatal mortality was $17.8 \%$ (Table 2 ). Early neonatal death was seen in $7.1 \%$ of cases. $4.4 \%$ of preterm deliveries came with intrauterine death. Antepartum haemorrhage, hypertension and fetal congenital malformation were common causes of still births (Table 3) whereas respiratory distress syndrome, birth asphyxia and septicaemia were common causes of early neonatal deaths (Table 4). Neonatal outcome was directly proportional to gestational age (Table 5) and birth weight of the baby. Neonatal mortality was highest in the babies born with birth weight less than 750 grams.

Table 1: Risk factors associated with Preterm Labour

\begin{tabular}{|l|l|l|}
\hline RISK FACTORS & No. OF CASES & PERCENTAGE \\
\hline PPROM & 180 & 19.1 \\
\hline HYPERTENSION & 159 & 16.9 \\
\hline ANAEMIA & 104 & 11 \\
\hline ANTEPARTUM HAEMORRHAGE & 58 & 6.2 \\
\hline IUD & 54 & 5.7 \\
\hline HYDRAMNIOS/MULTIPLE PREGNANCY & 52 & 5.4 \\
\hline CONGENITAL MALFORMATIONS & 30 & 3 \\
\hline OTHERS & 25 & 2.7 \\
\hline TOTAL & 662 & 70 \\
\hline
\end{tabular}

Table 2: Perinatal mortality in Preterm Births

\begin{tabular}{|l|l|l|}
\hline TYPE OF DEATH & NO. OF CASES & PERCENTAGE \\
\hline MACERATED STILL BIRTH & 42 & 4.4 \\
\hline FRESH STILL BIRTH & 59 & 6.3 \\
\hline EARLY NEONATAL DEATH & 68 & 7.1 \\
\hline TOTAL & 169 & 17.8 \\
\hline
\end{tabular}

Table 3: Risk factors associated with Still Birth in Preterm Labour 


\begin{tabular}{|c|c|c|}
\hline RISK FACTORS & 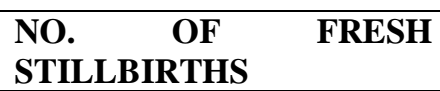 & $\begin{array}{l}\text { NO. OF MACERATED STILL } \\
\text { BIRTHS }\end{array}$ \\
\hline ANTEPARTUM HAEMORRHAGE & 22 & 10 \\
\hline $\begin{array}{ll}\text { PREGNANCY } & \text { INDUCED } \\
\text { HYPERTENSION } & \end{array}$ & 19 & 10 \\
\hline $\begin{array}{ll}\text { FETAL } & \text { CONGENITAL } \\
\text { MALFORMATION } & \\
\end{array}$ & 6 & 8 \\
\hline MATERNAL ANAEMIA & - & 6 \\
\hline BIRTH ASPHYXIA & 4 & - \\
\hline MATERNAL HEPATITIS & 2 & 4 \\
\hline OTHERS & 6 & 4 \\
\hline TOTAL & 59 & 42 \\
\hline
\end{tabular}

Table 4: Causes of Neonatal Deaths

\begin{tabular}{|l|l|l|}
\hline CAUSES & NO. OF CASES & PERCENTAGE \\
\hline R.D.S & 26 & 38.3 \\
\hline BIRTH ASPHYXIA & 16 & 23.5 \\
\hline SEPTICAEMIA & 11 & 16.3 \\
\hline $\begin{array}{l}\text { FETAL CONGENITAL } \\
\text { MALFORMATION }\end{array}$ & 5 & 7.3 \\
\hline MECONIUM ASPIRATION & 6 & 8.8 \\
\hline PULMONARY HAEMORRHAGE & 4 & 5.8 \\
\hline TOTAL & 68 & 100 \\
\hline
\end{tabular}

Table 5:Association of Perinatal Mortality with Gestational Age.

\begin{tabular}{|l|l|l|}
\hline GESTATIONAL AGE (weeks) & NO. OF CASES & PERCENTAGE \\
\hline$<28$ & 63 & 37.6 \\
\hline $28-32$ & 50 & 29.8 \\
\hline $32-34$ & 33 & 19 \\
\hline$>34$ & 23 & 13.6 \\
\hline TOTAL & 169 & 100 \\
\hline
\end{tabular}

\section{Discussion:-}

This clinical prospective study was carried out in a tertiary care teaching hospital for duration of 6 months. In the present study, the incidence of preterm birth was $21.5 \%$ which was higher than reported by Bangal et al [7] and Devi et al [8] where incidence were $13.2 \%$ and $12.18 \%$ respectively. The higher incidence could be due to many preterm high risk pregnancies referred to our hospital and associated risk factors necessitating a preterm birth for maternal and fetal indication. In the present study, $40 \%$ women were from poor socio-economic status whereas in a study reported from Bangal et al [7]95\% of cases were from poor socio-economic class. The reason for high poor socioeconomic class was that their study was carried out in a rural tertiary care teaching hospital catering patients from surrounding villages.

In the present study, it was found that $70 \%$ of preterm deliveries had associated risk factors. Molly et al [9](1970) found that $67 \%$ of premature births had some obvious risk factors associated with preterm labour and Bangal et al [7](2012) found the associated risk factor in 57\% of cases. In the present study the common risk factors were preterm premature rupture of membrane followed by hypertension, anemia and antepartum haemorrhage.

In the present study, $44.5 \%$ of preterm births were between 34 to $<37$ weeks of gestation. Similar reports were reported by Bangal et al [7]. In their study 50\% cases had pregnancy duration of 32 to 34 weeks. The reason for the selective rise in the "late preterm" group possibly was due to an increase in medical reasons necessitating a preterm delivery, changes in obstetric practice or both [10].

The perinatal mortality among premature babies is very high in developing countries due to low birth weight and prematurity. In the present study it was observed that perinatal mortality was directly related to birth weight and 
gestational age of the baby. Similar outcome was observed by Devi et al (1974) [8], Singh et al (1980) [11]and Bangal et al (2012)[7].

In the present study, the perinatal mortality was $17.8 \%$ as compared to $42.4 \%$ seen in a study conducted by Bangal et al [7]. The reason for low perinatal mortality in our hospital was due to availability of better neonatal care unit. The main risk factor associated with fresh still birth in the present study are acute placental insufficiency as a result of antepartum haemorrhage and severe hypertension. Fetal congenital malformation, severe anemia and hepatitis were responsible for antepartum fetal death. The most common cause for early neonatal death was respiratory distress syndrome seen in $38.3 \%$ of cases followed by birth asphyxia and septicaemia. Similar results were observed by Bangal et al (2012) [7] in their study.

Preventive measures like regular antenatal check-ups, screening of high risk cases, diagnosis and treatment of lower genital tract infections [12][13] by performing prophylactic encirclage in cases of cervical incompetence [14], use of short term tocolysis and glucocorticoids for improving lung maturity $[15,16]$, improving maternal nutrition leads to reducing the incidence of preterm labour and thereby reducing perinatal mortality. Neonatal septicaemia can be reduced by improving the aseptic conditions in the labour room and in the neonatal care unit and by use of broad spectrum antibiotics in preterm labour. Birth asphyxia can be reduced by improvement in neonatal care facilities.

\section{Conclusion:-}

Preterm onset of labour has a multifactorial etiology. Early detection and correction of risk factors like control of blood pressure in preeclampsia, correction of anemia, treatment of cervicovaginal infections and asymptomatic bacteriuria, avoidance of coitus in late pregnancy and cervical encirclage in proven cases of cervical incompetence can reduce the incidence of preterm labour. Maternal betamethasone for enhancing the fetal pulmonary maturity and reducing the incidence of respiratory distress syndrome in new born babies should be administered. All preterm deliveries should be conducted in tertiary care hospital where better perinatal care is available.

\section{Declaration of interest statement:-}

The authors report no declarations of interest.

\section{References:-}

1. Mc CormiekMC.(1985): The contribution of low birth weight to infant mortality and childhood morbidity. $\mathrm{N}$ Engl J Med., 312: 82-90

2. Beck S, WojdylaD, Say L, et al. (2010): The worldwide incidence of preterm births, a systematic review of maternal mortality \& morbidity. Bulletin of world health org 88:31.38

3. World Health Organization (2006): Neonatal and perinatal mortality: country,regional and global estimates. WHO, Geneva

4. Tucker JM, Goldenberg, RL, Davis RO, et al. (1991): Etiologies of preterm birth in an indigent population: Is prevention a logical expectation. Obstet Gynecol., 77: 343-347

5. Raju TNK.(2006): Epidermiology of late (near-term) preterm birth. Clin perinatal., 33:751-763

6. Preterm labour in Textbook of obstetrics by D.C Dutta $6^{\text {th }}$ ed. (2004): Published by new central book agency, Calcutta. Page 314-315

7. Bangal VB, Shinde KK, Gayatri KK, Patil NA. (2012): A study of risk factors and perinatal outcome in preterm labour at tertiary care hospital. International journal of Biomedical research.,3(3):147-150

8. Devi PK, Krishna Menon MK, Bhasker Rao K. (1980): Post Graduate Obstetrics and Gynaecology, $3^{\text {rd }}$ ed., Published by orient Longman ltd Madras. Page 204-209

9. Molly.P, Jain P.C and Prasad B.G. (1970) Environmental factors in preterm labour. J.Obstetrics and Gynae India.,20: 728.

10. Preterm birth trends in Greece, (1980-2008): A rising concern. BaroutisG, MousiolisA, Mesogitis S, Costalos C, Antsaklis A. ActaobstetGynecol Scand. 2013'29.

11. Singh M, Khare UN and Bhargava SK. Third International seminar on Maternal Mortality, Perinatal Mortality and Sterilisation, $3^{\text {rd }}-5^{\text {th }}$ October 1980, New Delhi

12. Leitich H, Bonder-Adler B, Brunbauer M, Kaider A, Egarter C, Husslein P. (2003): Bacterial vaginosis as a risk factor for preterm delivery: A meta-analysis Am J Obstet Gynecol.,189(1): 139-147

13. Morency AM, Bujold E. (2007):The effect of second trimester antibiotic therapy on the rate of preterm birth, J ObstetGynecol Can., 29(1):35-44 
14. BerghellaU, Baxter JK, Hendrix NW. Cervical assessment by ultrasound for preventing preterm delivery. Cochrane database of systematic reviews 2009; Issue 3. Art.no; CD 007235

15. American college of Obstetrician and Gynaecologists. Antenatal corticosteroid therapy for fatal maturation. Committee opinion no 419. (2008): Obstet Gynecol., 112: 963- 965.

16. American College of obstetrician and gynaecologists. (2008): Antenatal corticosteroid therapy for fetal maturation. COG committees opinion no 402. Obstet Gynecol., 111: 805. 